Review Article

\title{
Microbial Fuel Cell: Recent Developments in Organic Substrate Use and Bacterial Electrode Interaction
}

\author{
Fatin Syahirah Fadzli $\mathbb{D}^{1},{ }^{1}$ Showkat Ahmad Bhawani $\mathbb{D}^{2}{ }^{2}$ \\ and Rania Edrees Adam Mohammad ${ }^{3}{ }^{3}$ \\ ${ }^{1}$ Materials Technology Research Group (MaTRec), School of Chemical Sciences, Universiti Sains Malaysia, 11800 Minden, \\ Penang, Malaysia \\ ${ }^{2}$ Faculty of Resource Science and Technology, Universiti Malaysia Sarawak (UNIMAS), Kota Samarahan 94300, Malaysia \\ ${ }^{3}$ Open University of Sudan, Faculty of Education, Sciences Department, P.O. Box 13091, Khartoum, Sudan
}

Correspondence should be addressed to Rania Edrees Adam Mohammad; raniaadam37@gmail.com

Received 7 April 2021; Accepted 22 June 2021; Published 29 June 2021

Academic Editor: Marcelino Maneiro

Copyright (C) 2021 Fatin Syahirah Fadzli et al. This is an open access article distributed under the Creative Commons Attribution License, which permits unrestricted use, distribution, and reproduction in any medium, provided the original work is properly cited.

\begin{abstract}
A new bioelectrochemical approach based on metabolic activities inoculated bacteria, and the microbial fuel cell (MFC) acts as biocatalysts for the natural conversion to energy of organic substrates. Among several factors, the organic substrate is the most critical challenge in MFC, which requires long-term stability. The utilization of unstable organic substrate directly affects the MFC performance, such as low energy generation. Similarly, the interaction and effect of the electrode with organic substrate are well discussed. The electrode-bacterial interaction is also another aspect after organic substrate in order to ensure the MFC performance. The conclusion is based on this literature view; the electrode content is also a significant challenge for MFCs with organic substrates in realistic applications. The current review discusses several commercial aspects of MFCs and their potential prospects. A durable organic substrate with an efficient electron transfer medium (anode electrode) is the modern necessity for this approach.
\end{abstract}

\section{Introduction}

Over the past few years, there has been an increase in energy demand. Nonrenewable energy sources, such as fossil fuels and nuclear power, are widely used in the world [1]. When it comes to fossil fuels, this source of energy does more damage to the environment and continuous use of fossil fuels emits carbon dioxide, which becomes toxic when there is too much of it in the air. The rapid depletion of fossil fuels had a significant impact on human life through air pollution and global warming [2-4]. However, many nations worldwide have made outstanding attempts to find a viable alternative to address the energy issue by focusing on renewable sources of energy, such as solar energy, water energy, and wind energy [5-7]. These attempts provided a new way to produce electricity that utilizes a fuel cell through the use of metal catalysts of high value (in the conventional version). As a matter of fact, many benefits can be obtained by using fuel cell compared to other energy producers, such as emission of zero environmentally polluting gases, for example, $\mathrm{CO}_{2}, \mathrm{CO}$, NOx, and SOx, greater efficiency, and the absence of mobile components, resulting in less sonic 'pollution [8]. The only shortcomings of these new energy sources, on the other hand, are their high cost and high mass generation [8]. Microbial fuel cell (MFC) is a type of bioelectrochemical fuel cell that requires the presence of active bacteria that function as biocatalyst for bioenergy generation in anodic chambers $[9,10]$. In the year 1911, Potter [11] reported that bacteria were capable of generating current, but only after a period of 50 years, good results can be observed even they were very low in quantity [12]. Nevertheless, the fuel cell became the center of attention at the beginning of 1990s and as a result, the MFC technology also received attention [13]. In addition, more research was done in the year 1999, as it was known that the presence of a mediator is not a must for an MFC [14]. In general, MFC is composed of the chambers of 
cathode and anode isolated by the presence of proton exchange membrane (PEM), as shown in Figure 1. Organic substrates will undergo oxidation via the active biocatalyst located within an anode to form protons and electrons [16]. The PEM facilitates the migration of protons towards the cathode, whereas electrons are transferred via an external circuit. Both electrons and protons form a reaction in the cathodic chamber with simultaneous reduction of oxygen to form water. It is the biocatalyst existing in the anode chamber that facilitates the oxidation sources of substrate for the production of protons and electrons. At an anode, electricity generation is prevented by the presence of oxygen; thus, a design of a realistic system that can avoid oxygen from reacting with bacteria should be created, thus the anaerobic condition for the anode chamber [17]. In the past 10 years, the system of MFC has been drastically enhanced but with certain limitations in regard to practicability and scale-up issues, for instance, the resistance of membrane during transportation of protons and problems in both chambers $[18,19]$. In addition to the previous issues, MFC is also facing constriction in producing energy because energy generation through the MFC system is dependent on the concentration of the substrate. If the concentration of the substrates present is larger than a certain value, production of power will be obstructed $[20,21]$. The organic substrate is the most critical challenge. The lower stability of the organic substrate may have had an impact on remediation efficiency and energy generation because the organic substrate did not provide enough power to the bacterial population, resulting in poor MFC output. The long-term stability of organic substrates in MFC for industrial use should be the subject of future research. According to the literature survey, there is no similar information available on the interaction of electrode-bacteria and electrode effect in the presence of different organic substrates in MFC. This review provides a direction to researchers to improve the organic substrate factor with electrode development to ensure the strong interaction of bacteria with the electrode material. In the present review article, different organic substrates are extensively studied with bacterial interaction. The effects of different previous electrodes and electrode-bacteria interactions are also summarized in the present study.

\section{List of Organic Substrates Used in MFC}

One of the most crucial aspects of MFC is the substrates used due to their effect on the generation of electricity [22, 23]. Various substrates can be utilized in the MFC technology to facilitate energy generation, either pure substances or complex mixture from organic materials present in wastewater. The aim of all treatment processes is mainly to reduce the number of pollutants in water in order for it to be safe for utilization and the environment. Activated sludge process or ASP is often used for the treatment of wastewater; however, the downside of this substance is that it consumed a huge amount of energy and based on estimation, the total energy required to provide oxygen for ASPs in the United States of America is equal to near $2 \%$ of the total electricity used in the country [22]. In addition, in ASP treatment, a second treatment step is needed for the process, which ultimately classified the streams produced using this treatment for agroindustry as "raw material" instead of "waste" that can be further used to synthesize specific energy or chemical [24]. Furthermore, these days, waste management is more focused on how energy can be reused and recovered, which results in a new view on ways that these streams can be managed. A record of substrates that had been utilized for various MFC research is presented in Table 1. Due to the differences in parameters used for each MFC study, such as surface area, operational conditions, and electrode used, it is hard to compare the performances of MFC from the literature. Moreover, various researchers applied different units to indicate their MFC performances. A unit most often used is called current density that can signify the produced current per unit area of the surface area of anode $\left(\mathrm{mA} / \mathrm{cm}^{2}\right)$ or the current produced per volume of the cell $\left(\mathrm{mA} / \mathrm{cm}^{3}\right)$. From Table 1, the current density is written in the unit of $\mathrm{mA} / \mathrm{cm}^{2}$ for differentiation purposes. For articles that expressed the current density in terms other than $\mathrm{mA} / \mathrm{cm}^{2}$, the current density is obtained according to the dimensions of the electrode used and the reported current value at maximum power. The most frequently used substrates and the effects they bring towards the performance of MFC are discussed in detail.

2.1. Acetate. Acetate seems to be the common substrate for energy production in the majority of MFC research so far. As opposed to acetate, the recalcitrance of certain forms of wastewater makes them somewhat challenging to use [27]. Acetate behaves as a straightforward substrate that is widely utilized as a source of carbon to stimulate electroactive bacteria [22]. Due to its inert behavior to alternate conversions of microbial such as methanogenesis and fermentation at ambient temperature, acetate is widely utilized as substrate as an ideal model for new MFC materials, operating conditions, or reactor prototypes [47]. Furthermore, acetate is the final result of many metabolic routes for sources of carbon with higher order (along with the glucose metabolism Entner-Doudoroff pathway) [48].

Liu et al. [49] stated that using a single-chambered MFC fed with the provided power by acetate $\left(506 \mathrm{~mW} / \mathrm{m}^{2}\right.$, $800 \mathrm{mg} / \mathrm{L}$ ) was almost 66 percent larger than the one emitted by butyrate $\left(305 \mathrm{~mW} / \mathrm{m}^{2}, 1000 \mathrm{mg} / \mathrm{L}\right)$. Chae et al. [50] recently differentiated the power generation and CE efficiency of four types of substrates. MFC fed with acetate resulted in the largest value of CE (72.3\%), led by butyrate $(43.0 \%)$, propionate $(36.0 \%)$, and glucose $(15 \%)$. In contrast to wastewater enriched with protein as a substrate in MFC, the acetate-fed MFC obtained over two times the maximum power of electric and one-half of optimum resistance of external load as opposed to the MFC with protein-rich wastewater as the substrate [6]. Nonetheless, since wastewater with high amounts of protein is a dynamic substrate, there is a potential to enrich various microbial populations as compared to acetate. A variety of microbial populations aids in the utilization of different substrates or the conversion of organics to simple substances like acetate that can 


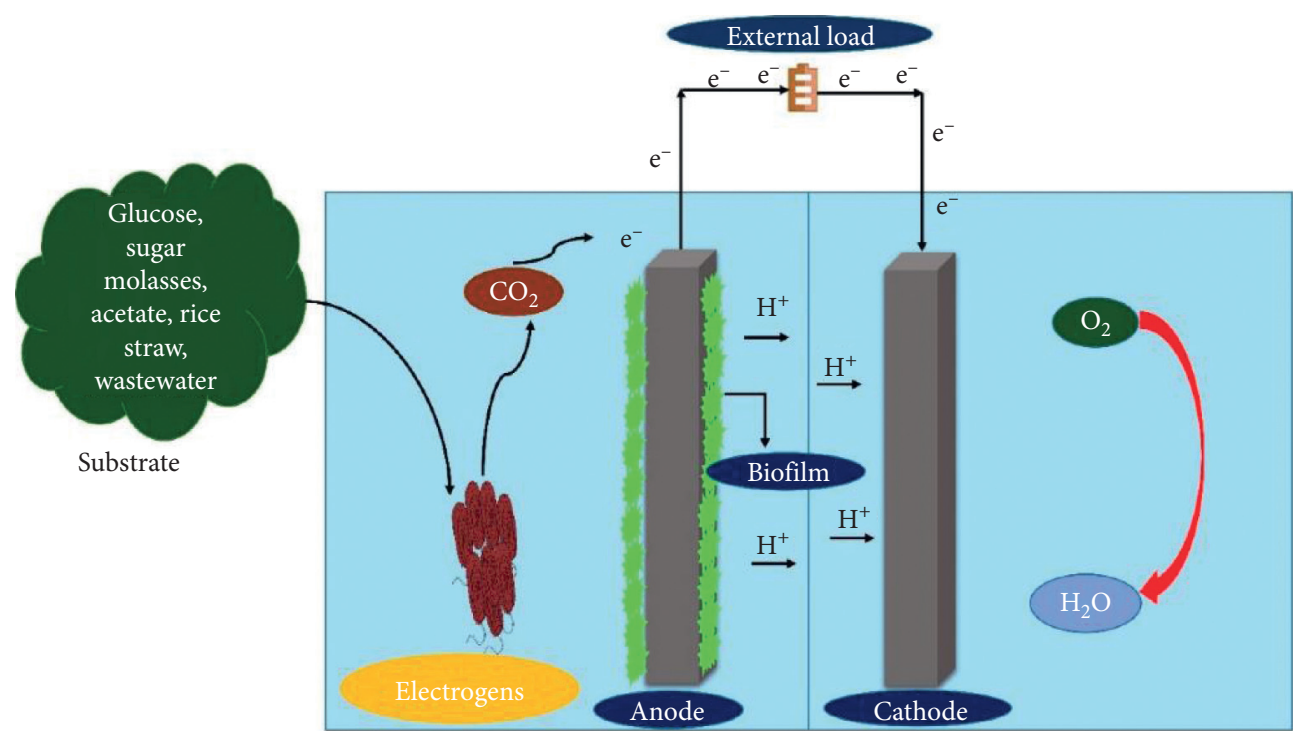

FIGURE 1: Systematic presentation of MFC (adapted from reference [15] with MDPI permission).

TABLE 1: Summary of the used substrates in MFC with performance.

\begin{tabular}{|c|c|c|c|c|c|}
\hline $\begin{array}{l}\text { List of organic } \\
\text { substrates }\end{array}$ & $\begin{array}{c}\text { Used } \\
\text { concentration }\end{array}$ & Inoculum source & $\begin{array}{l}\text { Type of MFC (with surface area of } \\
\text { electrode and/or volume of cell) }\end{array}$ & $\begin{array}{c}\text { Current } \\
\text { density } \\
\left(\mathrm{mA} / \mathrm{cm}^{2}\right)\end{array}$ & Reference \\
\hline Acetate & $1 \mathrm{~g} / \mathrm{L}$ & Preacclimated bacteria & $\begin{array}{l}\text { One-chamber MFC in the form of a } \\
\text { cube with a graphite fiber brush anode } \\
\text { (brush volume: } 7170 \mathrm{~m}^{2} / \mathrm{m}^{3} \text { ) }\end{array}$ & 0.8 & [25] \\
\hline Arabitol & $1220 \mathrm{mg} / \mathrm{L}$ & Preacclimated bacteria & $\begin{array}{l}\text { MFC }(12 \mathrm{~mL}) \text { with nonwet proofed } \\
\text { carbon cloth as an anode }\left(2 \mathrm{~cm}^{2}\right) \text { and } \\
\text { wet proofed carbon cloth as a cathode } \\
\qquad\left(7 \mathrm{~cm}^{2}\right) \text { in one chamber }\end{array}$ & 0.68 & {$[26]$} \\
\hline $\begin{array}{l}\text { Azo dye with } \\
\text { glucose }\end{array}$ & $300 \mathrm{mg} / \mathrm{L}$ & $\begin{array}{c}\text { Mixture of anaerobic and aerobic } \\
\text { sludge }\end{array}$ & $\begin{array}{c}\text { MFC with a single-chamber air- } \\
\text { cathode and a carbon paper anode } \\
\left(36 \mathrm{~cm}^{2}\right)\end{array}$ & 0.09 & [27] \\
\hline $\begin{array}{l}\text { Carboxymethyl } \\
\text { cellulose (CMC) }\end{array}$ & $1 \mathrm{~g} / \mathrm{L}$ & $\begin{array}{l}\text { Clostridium celluloticum and } \\
\text { G. sulfurreducens }\end{array}$ & $\begin{array}{l}\text { MFC with two chambers and graphite } \\
\text { plates as electrodes }\left(16 \mathrm{~cm}^{2}\right) \text {, as well as } \\
\text { ferricyanide catholyte }\end{array}$ & 0.05 & {$[28]$} \\
\hline Cellulose particles & $4 \mathrm{~g} / \mathrm{L}$ & $\begin{array}{l}\text { Pure culture of Enterobacter } \\
\text { cloacae }\end{array}$ & $\begin{array}{c}\text { Carbon cloth anode }\left(1.13 \mathrm{~cm}^{2}\right) \text { and } \\
\text { carbon fibers as the cathode in a U- } \\
\text { tube MFC }\end{array}$ & 0.02 & [28] \\
\hline $\begin{array}{l}\text { Corn stover } \\
\text { biomass }\end{array}$ & $1 \mathrm{~g} / \mathrm{L}$ & Domestic wastewater & $\begin{array}{c}\text { Carbon paper anode }\left(7.1 \mathrm{~cm}^{2}\right) \text { and } \\
\text { carbon cloth cathode in a one- } \\
\text { chamber membrane-less air-cathode } \\
\text { MFC }\end{array}$ & 0.15 & {$[29]$} \\
\hline Cysteine & $385 \mathrm{mg} / \mathrm{L}$ & $\begin{array}{l}\text { Sediment sample from depth of } \\
\qquad 30 \mathrm{~cm}\end{array}$ & $\begin{array}{l}\text { MFC with two chambers and carbon } \\
\text { paper electrodes }\left(11.25 \mathrm{~cm}^{2}\right)\end{array}$ & 0.0186 & [30] \\
\hline 1,2-Dichloroethane & $99 \mathrm{mg} / \mathrm{L}$ & $\begin{array}{l}\text { Microbial consortia from MFC } \\
\text { enriched with acetate }\end{array}$ & $\begin{array}{c}\text { Two-chambered MFC with graphite } \\
\text { plate anode }\left(20 \mathrm{~cm}^{2}\right) \text { and graphite } \\
\text { granules cathode }\end{array}$ & 0.008 & [31] \\
\hline Furfural & $6.8 \mathrm{mM}$ & $\begin{array}{c}\text { Preacclimated bacteria from } \\
\text { anode of a ferricyanide-cathode } \\
\text { MFC }\end{array}$ & $\begin{array}{l}\text { Carbon paper anode and cathode in a } \\
\text { one-chamber air-cathode MFC } \\
\qquad\left(7 \mathrm{~cm}^{2}\right)\end{array}$ & 0.17 & {$[32]$} \\
\hline Galactitol & $1220 \mathrm{mg} / \mathrm{L}$ & $\begin{array}{c}\text { Preacclimated bacteria from } \\
\text { MFC }\end{array}$ & $\begin{array}{l}\text { MFC }(12 \mathrm{~mL}) \text { with nonwet proofed } \\
\text { carbon cloth as anode }\left(2 \mathrm{~cm}^{2}\right) \text { and wet } \\
\text { proofed carbon cloth as cathode } \\
\left(7 \mathrm{~cm}^{2}\right) \text { in one chamber }\end{array}$ & 0.78 & {$[26]$} \\
\hline
\end{tabular}


TABle 1: Continued.

\begin{tabular}{|c|c|c|c|c|c|}
\hline $\begin{array}{l}\text { List of organic } \\
\text { substrates }\end{array}$ & $\begin{array}{c}\text { Used } \\
\text { concentration }\end{array}$ & Inoculum source & $\begin{array}{l}\text { Type of MFC (with surface area of } \\
\text { electrode and/or volume of cell) }\end{array}$ & $\begin{array}{c}\text { Current } \\
\text { density } \\
\left(\mathrm{mA} / \mathrm{cm}^{2}\right) \\
\end{array}$ & Reference \\
\hline Glucose & $6.7 \mathrm{mM}$ & $\begin{array}{c}\text { Mixed bacterial culture } \\
\text { maintained on sodium acetate for } \\
1 \text { year (Rhodococcus and } \\
\text { Paracoccus) }\end{array}$ & $\begin{array}{l}\text { MFC }(12 \mathrm{~mL}) \text { with a one-chamber air- } \\
\text { cathode and nonwet proofed carbon } \\
\text { cloth as anode }\left(2 \mathrm{~cm}^{2}\right) \text { and wet } \\
\text { proofed carbon cloth as cathode } \\
\qquad\left(7 \mathrm{~cm}^{2}\right)\end{array}$ & 0.70 & {$[33]$} \\
\hline Lactate & $18 \mathrm{mM}$ & $\begin{array}{l}\text { Pure culture of } S \text {. oneidensis } \\
\text { MR-1 }\end{array}$ & $\begin{array}{c}\text { MFC with two chambers and graphite } \\
\text { felt electrode }\left(20 \mathrm{~cm}^{2}\right)\end{array}$ & 0.005 & {$[34]$} \\
\hline Landfill leachate & $6000 \mathrm{mg} / \mathrm{L}$ & Leachate and sludge & $\begin{array}{c}\text { MFC with two chambers and a carbon } \\
\text { veil electrode }\left(30 \mathrm{~cm}^{2}\right)\end{array}$ & 0.0004 & {$[35]$} \\
\hline $\begin{array}{l}\text { Macroalgae, Ulva } \\
\text { lactuca }\end{array}$ & $2500 \mathrm{mg} / \mathrm{L}$ & $\begin{array}{l}\text { Primary clarifier overflow of a } \\
\text { wastewater plant }\end{array}$ & $\begin{array}{l}\text { Graphite brush anodes and a } \\
\text { platinized cathode in a one-chamber } \\
\text { air-cathode MFC }(25 \mathrm{~mL})\end{array}$ & 0.25 & {$[36]$} \\
\hline $\begin{array}{l}\text { Microalgae, } \\
\text { Chlorella vulgaris }\end{array}$ & $2500 \mathrm{mg} / \mathrm{L}$ & $\begin{array}{l}\text { Primary clarifier overflow of a } \\
\text { wastewater plant }\end{array}$ & $\begin{array}{l}\text { Graphite brush anodes and a } \\
\text { platinized cathode in a one-chamber } \\
\text { air-cathode MFC }(25 \mathrm{~mL})\end{array}$ & 0.20 & {$[37]$} \\
\hline Ribitol & $1220 \mathrm{mg} / \mathrm{L}$ & $\begin{array}{c}\text { Preacclimated bacteria from } \\
\text { MFC }\end{array}$ & $\begin{array}{l}\text { MFC }(12 \mathrm{~mL}) \text { with nonwet proofed } \\
\text { carbon cloth as anode }\left(2 \mathrm{~cm}^{2}\right) \text { and wet } \\
\text { proofed carbon cloth as cathode } \\
\left(7 \mathrm{~cm}^{2}\right) \text { in one chamber }\end{array}$ & 0.73 & {$[33]$} \\
\hline Sodium formate & $20 \mathrm{mM}$ & $\begin{array}{l}\text { Anaerobic digested fluid from a } \\
\text { sewage treatment plant }\end{array}$ & $\begin{array}{l}\text { MFC with two chambers and graphite } \\
\text { felt electrodes }\left(4.5 \mathrm{~cm}^{2}\right)\end{array}$ & 0.22 & {$[37]$} \\
\hline Sodium fumarate & $25 \mathrm{mM}$ & Pure culture of G. sulfurreducens & $\begin{array}{l}\text { Half-cells of stainless steel cathode } \\
\left(2.5 \mathrm{~cm}^{2}\right) \text { poised at }-600 \mathrm{mV} \text { against } \\
\mathrm{Ag} / \mathrm{AgCl}\end{array}$ & 2.05 & {$[38]$} \\
\hline Sucrose & $2674 \mathrm{mg} / \mathrm{L}$ & $\begin{array}{l}\text { Anaerobic sludge from septic } \\
\text { tank }\end{array}$ & $\begin{array}{l}\text { MFC in two chambers of woven } \\
\text { graphite anode }\left(7 \mathrm{~cm}^{2}\right) \text { and } \\
\text { ferricyanide catholyte }\end{array}$ & 0.19 & {$[39]$} \\
\hline $\begin{array}{l}\text { Xylose and humic } \\
\text { acid }\end{array}$ & $10 \mathrm{mM}$ & Domestic wastewater & $\begin{array}{l}\text { MFC with two chambers and plain } \\
\text { carbon paper as electrode }\left(76.5 \mathrm{~cm}^{2}\right)\end{array}$ & 0.06 & {$[40]$} \\
\hline $\begin{array}{l}\text { Brewery } \\
\text { wastewater }\end{array}$ & $600 \mathrm{mg} / \mathrm{L}$ & Anaerobic mixed consortia & $\begin{array}{l}\text { One-chamber air-cathode MFC with } \\
\text { carbon fibers as anode }\end{array}$ & 0.18 & {$[41]$} \\
\hline $\begin{array}{l}\text { Chocolate industry } \\
\text { wastewater }\end{array}$ & $1459 \mathrm{mg} / \mathrm{L}$ & Activated sludge & $\begin{array}{l}\text { MFC with two chambers and } \\
\text { ferricyanide as catholyte, with graphite } \\
\text { rods as electrodes }\left(16.485 \mathrm{~cm}^{2}\right) \text { and } \\
\text { ferricyanide as catholyte }\end{array}$ & 0.302 & {$[42]$} \\
\hline $\begin{array}{l}\text { Domestic } \\
\text { wastewater }\end{array}$ & $600 \mathrm{mg} / \mathrm{L}$ & Anaerobic sludge & $\begin{array}{c}\text { MFC with a two-chambered } \\
\text { mediator-free chamber and a simple } \\
\text { graphite electrode }\left(50 \mathrm{~cm}^{2}\right)\end{array}$ & 0.06 & {$[43]$} \\
\hline $\begin{array}{l}\text { Protein-rich } \\
\text { wastewater }\end{array}$ & $1.75 \mathrm{~g} / \mathrm{L}$ & Mesophilic anaerobic sludge & $\begin{array}{l}\text { MFC with two chambers and graphite } \\
\text { rods as electrodes }\left(65 \mathrm{~cm}^{2}\right)\end{array}$ & 0.008 & {$[44]$} \\
\hline $\begin{array}{l}\text { Real urban } \\
\text { wastewater }\end{array}$ & $330 \mathrm{mg} / \mathrm{L}$ & Domestic wastewater & $\begin{array}{c}\text { A salt bridge connects the anolyte } \\
\left(1000 \mathrm{~cm}^{3}\right) \text { and catholyte }\left(100 \mathrm{~cm}^{3}\right) \\
\text { chambers; graphite cylinder anode } \\
\left(20 \mathrm{~cm}^{2}\right)\end{array}$ & 0.018 & {$[45]$} \\
\hline $\begin{array}{l}\text { Starch processing } \\
\text { wastewater }\end{array}$ & $4852 \mathrm{mg} / \mathrm{L}$ & Starch processing wastewater & $\begin{array}{l}\text { MFC with a single-chamber air- } \\
\text { cathode and a carbon paper anode } \\
\left(25 \mathrm{~cm}^{2}\right)\end{array}$ & 0.09 & {$[44]$} \\
\hline $\begin{array}{l}\text { Synthetic } \\
\text { wastewater }\end{array}$ & $16 \mathrm{~g}$ & $\begin{array}{c}\text { Granular sludge from upflow } \\
\text { anaerobic sludge blanket (UASB) } \\
\text { reactor }\end{array}$ & $\begin{array}{c}\text { MFC with glassy carbon electrodes } \\
\left(160 \mathrm{~cm}^{2}\right) \text { that is membrane-less and } \\
\text { mediator-free }\end{array}$ & 0.17 & {$[46]$} \\
\hline $\begin{array}{l}\text { Synthetic } \\
\text { wastewater }\end{array}$ & $510 \mathrm{mg} / \mathrm{L}$ & $\begin{array}{c}\text { Anaerobic culture from a } \\
\text { preexisting MFC }\end{array}$ & $\begin{array}{l}\text { Stainless steel as anode }\left(170 \mathrm{~cm}^{2}\right) \text { and } \\
\text { graphite rods as cathode }\left(150 \mathrm{~cm}^{2}\right) \text { in a } \\
\text { dual-chamber MFC }\end{array}$ & 0.008 & [39] \\
\hline
\end{tabular}

function as donors of electrons in current processing. Bacteria in MFCs oxidize organic substrates, such as acetate, and other sugars to produce electrons. The oxidation reaction is carried out by the anode, whereas the reduction process is carried out by the cathode. The biological reaction of acetate can be written as follows: 
(a) If acetate is used as organic substrate,

oxidation reaction at anode is $\mathrm{CH}_{3} \mathrm{COOH}+2 \mathrm{H}_{2} \mathrm{O}$ $\longrightarrow 2 \mathrm{CO}_{2}+8 \mathrm{H}^{+}+8 \mathrm{e}^{-}$

reduction reaction at cathode is $8 \mathrm{H}^{+}+8 \mathrm{e}^{-}+2 \mathrm{O}_{2}$ $\longrightarrow 4 \mathrm{H}_{2} \mathrm{O}$

overall reaction is $\mathrm{CH}_{3} \mathrm{COOH}+2 \mathrm{O}_{2}$ $\longrightarrow 2 \mathrm{CO}_{2}+2 \mathrm{H}_{2} \mathrm{O}+$ electricity + biomass

2.2. Glucose. Another type of popular substrate for MFC is glucose. According to Kim et al. [51], the output of an MFC comprising Proteus vulgaris relies on the sources of carbon in the microorganism's initial medium, whereas glucose prompted cells within MFC ran for a shorter span of time than galactoseinitiated cells. Fed-batch MFC enriched with glucose employing $100 \mathrm{mM}$ ferric cyanide as the oxidation agent for cathode yielded a peak power density value of $216 \mathrm{~W} / \mathrm{m}^{3}$, as reported by Rabaey et al. [52]. Hu et al. [53] contrasted the viability of using sediment of anaerobic conditions as a MFC fuel for energy production to glucose. Anaerobic sludge was utilized as a very small substrate in a baffle-chamber membrane-less MFC, and only $0.3 \mathrm{~mW} / \mathrm{m}^{2}$ of power was provided. In the same method, however, glucose produced the highest output value of $161 \mathrm{~mW} / \mathrm{m}^{2}$. One more research compared the energy conversion efficiency (ECE) of glucose and acetate substrates for MFC [54]. With acetate, the ECE value was 42 percent, but using glucose, it was just 3 percent, resulting in reduced power density and current. According to Chae et al. [50], MFC fed with glucose had the poorest ECE due to electron depletion by bacterial competition, but their comparatively distinct bacterial composition allowed for much broader substrate use and the highest PD. The poor ECE value was attributed to the assumption that glucose can be a fermentable medium, meaning that it is used by a variety of competitive metabolisms that do not generate energy, like methanogenesis and fermentation. Chae et al. [50] suggested that the existence of an even more dynamic mixed consortium of different electricigens or their syntrophic bacteria as an outcome of the development of diverse fermentation byproducts through degradation of glucose to justify the glucose-enriched MFC much broader substrate specificity than the others. Organic substrates such as glucose, acetate, sucrose, and other sugars are oxidized by bacteria in MFCs to generate electrons. The anode performs the oxidation reaction, whereas the cathode performs the reduction reaction. The glucose biochemical reaction can be written as follows:

(b) If glucose is used as organic substrate,

oxidation reaction at anode is $\mathrm{C}_{6} \mathrm{H}_{12} \mathrm{O}_{6}+6 \mathrm{H}_{2} \mathrm{O}$ $\longrightarrow 6 \mathrm{CO}_{2}+24 \mathrm{H}^{+}+24 \mathrm{e}^{-}$

reduction reaction at cathode is $24 \mathrm{H}^{+}+24 \mathrm{e}^{-}+6 \mathrm{O}_{2}$ $\longrightarrow 12 \mathrm{H}_{2} \mathrm{O}$

overall reaction is $\mathrm{C}_{6} \mathrm{H}_{12} \mathrm{O}_{6}+6 \mathrm{O}_{2} \longrightarrow 6 \mathrm{CO}_{2}+6$ $\mathrm{H}_{2} \mathrm{O}+$ electricity + biomass

2.3. Lignocellulosic Biomass. Due to the availability and renewability, lignocellulosic compounds derived from residues of agriculture are a favorable feedstock for low-cost electricity generation [55]. Nonetheless, microorganisms in MFC are unable to explicitly use lignocellulosic biomass for energy production. It must be degraded into monosaccharides or other reduced matters [56]. Catal et al. [33] showed that every monosaccharide, which can be produced directly from lignocellulosic biomass hydrolysis, was a decent energy source in MFC. Utilizing cellulose as base, energy production necessitates the presence of a microbial population that is capable of both exoelectrogenic and cellulolytic activities [57]. Zuo et al. [29] investigated energy production in MFC from biomass of corn stover waste through samples synthesized by acidic or neutral steam-exploded hydrolysis operations that form soluble sugars from hemicellulose. The maximal PDs for neutral hydrolysates and acid hydrolysates (1000 mg COD/L, $250 \mathrm{x}$ ) were $371 \mathrm{~mW} / \mathrm{m}^{2}$ and $367 \mathrm{~mW} / \mathrm{m}^{2}$, respectively, by making use of an air-cathode with a layer of diffusion and improved conductivity of solution $(20 \mathrm{mS} / \mathrm{cm})$. Raw corn stover was recently demonstrated as a single-chambered MFC substrate for the production of electricity, but the power output was significantly lower than when glucose was utilized as the substrate [58]. There are yet to be discovered any appropriate microorganisms to convert pentose (an important part in lignocellulose hydrolysates) into bioethanol, leaving a significant portion of residual plant matter unfit for bioethanol development. At a $10 \mathrm{mM}$ concentration of xylose (typical pentose), the $\mathrm{PD}$ was $69 \mathrm{~mW} / \mathrm{m}^{2}$, a lower value as compared to that of PD for glucose $\left(97 \mathrm{~mW} / \mathrm{m}^{2}\right.$ with similar concentration), meaning that xylose is harder to be used for the production of power unlike glucose [40].

2.4. Synthetic Wastewater. Several researchers use artificial or chemical wastewater of clear composition because it is simple to monitor in regard to loading pressure, conductivity, and pH. Venkata Mohan et al. [36] achieved variable efficiency by using synthetic wastewater at varying rates of loading in MFC with similar configurations. A few media used during bacterial growth contain large quantities of redox mediators, including high-intensity wastewater composed of reduced species of sulphur and cysteine that can serve as an abiotic donor of electrons and improved power output for a brief period of time [59]. However, this does not adequately reflect the system's performance. One solution for this is by utilizing a minimum salt solution containing only one electron donor, like glucose or acetate. Rodrigo et al. [45] fed MFC with different types of synthetic wastewaters but with the same organic contaminants, such as peptone and glucose, and organic loading of $315 \mathrm{mg} / \mathrm{dm}^{3}$ but with a distinct ratio of readily biodegradable substrate to observe how wastewater composition affected MFC efficiency. The waste-fed MFC that is slowly biodegradable generates higher energy, most likely because of the formation of intermediates that favor the production of electricity.

2.5. Brewery Wastewater. Brewery wastewater is a preferred substrate in MFC because the strength is low and also because the organic matter is derived from food, thus resulting in low inhibitory compound concentrations, such as ammonia contained in animal wastewater [60]. A variety of 
wastewater from breweries differs in their concentration, approximately more concentrated as compared to domestic wastewater by 10 -fold ranging from 3000 to $5000 \mathrm{mg} \mathrm{COD} / \mathrm{L}$ [61]. As it contains a high amount of carbohydrate and less concentration of ammonium nitrogen, brewery wastewater comes off as a decent MFC substrate. Feng et al. [62] had studied the treatment of beer brewery wastewater, making use of an air-cathode MFC. According to the report, a peak $\mathrm{PD}$ value of $528 \mathrm{~mW} / \mathrm{m}^{2}$ was obtained after the addition of a $50 \mathrm{mM}$ phosphate buffer into the wastewater. This is a lower value of maximum power in contrast to the one obtained from domestic wastewater at comparable strength. This may be the result due to the different conductivities of both wastewaters. When using deionized water to dilute the concentration of the wastewater from a brewery, it results in a decreased value of conductivity of solution, which was $0.12 \mathrm{mS} / \mathrm{cm}$. Wen et al. [41] had recently utilized a model based on the MFC polarization curve and from the findings, the loss of mass transport and reaction kinetic $(0.248 \mathrm{~V}$ for both at $1.79 \mathrm{~A} / \mathrm{m}^{2}$ current density) was reported as the main factors that affected MFC performance for wastewater from the brewery. These losses can be evaded by raising the wastewater concentration and the temperature of the reaction and utilizing rough electrodes to give more sites for the reaction to occur.

2.6. Dye Wastewater. The biggest chemical class of synthetic dyes is made up of azo dyes, which are abundant in the effluent of textile and dye manufacturing industries. It is very crucial to get rid of dyes from these effluents before release as the presence of high dye concentrations will result in very serious environmental issues like blocking the transfer of oxygen and light into water, which will gravely affect aquatic life [63]. Other than that, in nature, dyes can be toxic; thus, in recent years, a lot of efforts are put into using dyes as an MFC substrate for removal of color from wastewater containing dye with simultaneous electricity production. A report by Sun et al. [27], when confectionary and glucose wastewater were utilized as cosubstrates in MFC, a model azo dye, ABRX3, or active brilliant red X-3B was quickly removed. However, dye with a high concentration of up to $1500 \mathrm{mg} / \mathrm{L}$ did not show decolorization, but the generation of energy from glucose is achieved with an increased concentration of more than $300 \mathrm{mg} / \mathrm{L}$ ABRX3. The competition between anode for electrons from sources of carbon and azo dye contributed to this result. Consequently, treatment of wastewater containing azo dye and wastewater containing organic matter that is easily biodegraded simultaneously can be performed by combining the two different types of wastewater in MFC that can both improve cost and energy [64]. The downside is that this process still needs significant development to find a dense bacterial community capable of applying dyes mixed with simple sources of carbon to provide a solution that is realistic using MFC to treat this wastewater.

2.7. Inorganic and Other Substrates. A research group investigated the production of electricity from anodic sulphide oxidation, which yielded a $\mathrm{PD}$ value of $39 \mathrm{~mW} / \mathrm{L}$ [65].
Simultaneous treatment of wastewater of paper recycling plants and generation of electricity by MFC gives a maximum value of $672 \mathrm{~mW} / \mathrm{m}^{2} \mathrm{PD}$ after using phosphate buffer [66]. Wastewater that is not treated with a phosphate buffer only has a power output $=144 \mathrm{~mW} / \mathrm{m}^{2}$ because the conductivity of the solution is low. Both production of current and phenol degradation were reported by Luo et al. [67], where the produced power is low as compared to glucose. There is also a substantial loss, which was less than $10 \%$ of ECE. According to Kaparaju et al. [68], a possible energy source can be found from the high amount of wastewater from integrated biorefineries. Borole et al. [69] had reported a simultaneous use of MFC for fermentation inhibitors such as vanillic acid, 5-hydroxymethylfurfural, furfural, 4-hydroxyacetophenone, and 4-hydroxybenzaldehyde removal from cellulosic biorefineries along with energy generation. A continuous anaerobic process by combining MFC with a fermenter of carbon monoxide had also been studied [70]. Acetate was synthesized by enrichment of fermented CO to feed MFC for electricity generation. The transformation of electricity from syn-gas (mainly $\mathrm{CO}$ ) can be shown even if the yield of conversion was small through microbial processes. Degradation of 1,2-dichloroethane using acidophilic bacteria was also reported [31]. Moreover, a single-chambered MFC with Desulfovibrio desulfuricans as source inoculum was investigated for the elimination of thiosulfate and sulfate and $0.115 \mathrm{~mA} / \mathrm{cm}^{2}$ of peak current was produced [71].

\section{Effect of Anode in MFC}

In order to produce electrons, microorganisms have a significant role in an anode chamber. After the produced electrons pass through the external circuit of a cell, they will facilitate the acceptors of electron reduction in the cathode. Similarly, the generated protons must also thrust through the proton exchange membrane (PEM) towards the cathode from the anode so that the circuit can be completed. These steps will simultaneously work to generate electricity and remove organic waste [21]. As the anaerobic anode chamber is part of the most important component for an MFC, all vital factors are present in this chamber for biomass degradation. An anode chamber consists of a microorganism, mediator, which is optional, substrate, and acceptor of electron electrode [21]. The energy of activation needed for reactions at anode should be lowered in proportion with the catalysts. The catalyst is normally the bacteria present in the chamber of the anode [21, 72-74].

In general, there are a lot of factors that can affect MFC performances, such as the configuration of equipment and the material used for electrodes [75]. It is crucial to stabilize these factors for the development of MFC. Anodic microbial transfer of electron is deemed as a part of the most important agents that can effectively improve MFC performances to raise the transfer rate of the microbial electron by various types of ways that can be applied, for instance, optimizing the design of electrode and cell and mediators of electron addition. Based on these factors, it can be clearly seen that 
electrodes are crucial parts for an MFC that can make or break its performance. Thus, a lot of research to study many types of materials for an electrode had been performed $[59,76]$. Moreover, for an electrode to be ideal, the materials should possess certain features: (1) satisfactory conduction of electricity and little resistance; (2) corrosion resistance and chemical stability; (3) biocompatibility; (4) suitable toughness and mechanical strength; (5) high surface area [9]. Materials that are made of carbon are the most common for an electrode, including those that contain carbon cloth and paper, graphite rod and fiber brush, felt of carbon, and reticulated vitreous carbon or RVC due to the good electrical conduction, stable microbial cultures, and high surface area [9]. Other than that, granular activated carbon (GAC), also known as graphite granules (GGs), also showed a high degree of activities of catalysts and microporosity, good conductivity, and low cost [77, 78]. Modified anode electrodes can improve MFC performance and because of this factor, more studies recently have focused on modifying anode using various techniques of nanoengineering to simplify the transfer of electrons. Furthermore, improvement of power density and increasing the potential of accepting electrons through modifying nanomaterials and techniques of heterogeneous fabrication had been researched [79]. Based on a report by Qiao et al. [80], utilizing carbon nanotubes or CNTs with polyaniline materials for anode can increase the feasibility of electron transfer and surface area of the electrode. A practical method to increase the output power of MFC is through using an anode made up of metal and modified carbon along with conductive polymers [81]. Attention should be given to the stability of electrodes when dealing with microorganisms present in substrates and organic polymers. Among various types of conductive polymers, the most commonly used for anode electrode modification is polyaniline (PANI) [82]. It has been reported that densities of current could be improved by using PANI polymers that had been modified, such as fluorinated PANI [23] and mixture of PANI/titanium dioxide [83]. Another suitable material for anode electrode is the composite of CNTs with polyaniline [84]. In addition, the performance of MFC could also be developed by the determination of anode composition [85]. Polytetrafluoroethylene (PTFE) that possesses hydrophobic behavior and chemical stability was used as an electrode for MFC. Zhang et al. also studied that composite of graphite/ PTFE with $30 \% \mathrm{w} / \mathrm{w}$ of PTFE is a great anode to generate electricity with power density production of $760 \mathrm{~mW} / \mathrm{m}^{2}$ and Escherichia coli biocatalyst [86]. Some respective anode performances of previous studies are presented in Table 2.

\section{Effect of Cathode in MFC}

In the chamber of the anode, protons will be produced, and these protons will transfer to the cathode by proton exchange membrane; as a result, the circuit is completed. The generated electron (equations 1 and 2) will transfer onto oxygen after moving towards the cathode chamber. The resulting oxygen is radical oxygen and its positive ions will be synthesized at anode producing water that will spread along the permeable membrane of ion at the cathode with the help of catalyst as follows [99]:

$$
\begin{gathered}
\mathrm{H}_{2} \longrightarrow 2 \mathrm{H}^{+}+2 \mathrm{e}^{-}, \\
\mathrm{O}^{2}+4 \mathrm{H}^{+}+4 \mathrm{e}^{-} \longrightarrow 2 \mathrm{H}_{2} \mathrm{O} .
\end{gathered}
$$

In this process, a steady current is produced when the cathode and anode are connected with wire [100]. The acceptor of electron species and concentration, the performance of catalyst, presence of protons, and structure of electrode have a tremendous impact on the cathode reaction yield. For cathodic and anodic reactions, catalysis is required, and a suitable catalyst can definitely help in improving the rate of reaction and decreasing the energy of activation [101]. Oxygen, which is abundant in the cathode chamber, is commonly utilized as the last acceptor electron because of the high potential of oxidation and formation of water, which is nonpoisonous at the end of reaction and is beneficial for the environment [102].

However, the issue of slow oxygen reduction kinetic even if a high potential is generated when plain graphite is utilized in MFC needs to be addressed by using an equivalent catalyst [91]. One catalyst that has been suggested to solve this problem is Potassium Ferricyanide $\left(\mathrm{K}_{3}[\mathrm{Fe}(\mathrm{CN})]\right)$ [92]. On the other hand, $\mathrm{K}_{3}[\mathrm{Fe}(\mathrm{CN})]$ needs to be refilled manually with passing time because of regeneration issues as $\mathrm{K}_{3}[\mathrm{Fe}$ $(\mathrm{CN})$ ] is not sufficiently oxidized by oxygen [93]. At the same time, $\mathrm{K}_{3}[\mathrm{Fe}(\mathrm{CN})]$ modified the anaerobic environment of the anode chamber via PEM [9]. Ferricyanide is beneficial as it produces small overpotential on simple electrodes made from carbon. The abiotic platinum catalyst is also often used for reactions occurring at cathode, but platinum itself is not an ideal catalyst for MFC because of its toxic behavior towards certain substrates [103]. Researchers usually added another oxidant, for example, artificial mediators for electron redox into the cathodic chamber, i.e., potassium permanganate, in order to raise the performance of MFC [104]. Najafpour et al. [105] reported that power, current, and voltage values can be increased with a low amount of potassium permanganate acting as an agent for oxidation. In MFC, the cathode is put into the compartment at one side and external surrounding on another. On the air side, the existence of Co catalyst facilitates the performance of MFC, but waterproofing may cause a limit of protons towards the catalyst [106]. Biocathodes have been a probable solution for the issues of catalysis specifications for oxidation of oxygen at cathode [107]. Biocathodes required utilization of microorganisms catalyst to facilitate reactions at the cathode for the improvement of energy generation using MFC, which will be an ideal cathode substitute rather than synthetic mediators or nitrate, tetrachloroethene, perchlorate, fumarate, sulfate catalysts, and electron acceptors such as $\mathrm{Co}$, trichloroethene, $\mathrm{Fe}(\mathrm{III}), \mathrm{U}(\mathrm{VI}), \mathrm{H}^{+}$, and $\mathrm{Cr}(\mathrm{VI})$ without utilizing exogenous [108]. Lower cost and configuration of biocathodes give them an advantage for them to be utilized instead of abiotic cathode, and as a result, highcost mediators and catalysts like Pt are unnecessary [21]. Biocathodes also produce practical end products and the 
TABle 2: Different MFC performances with their respective anode.

\begin{tabular}{|c|c|c|c|c|c|}
\hline Substrate & Anode & Bacteria & $\begin{array}{l}\text { Configuration of the } \\
\text { system }\end{array}$ & $\begin{array}{l}\text { Maximum PD } \\
\left(\mathrm{mW} / \mathrm{m}^{2}\right)\end{array}$ & References \\
\hline Glucose & Carbon paper & Geobacter SPP (firmicutes) & Two-chamber & $40.3 \pm 3.9$ & [87] \\
\hline Glucose & Graphite & Saccharomyces cerevisiae & Two-chamber & 16 & {$[88]$} \\
\hline Acetate & Carbon paper & G. sulfurreducens & Two-chamber & $48.4 \pm 0.3$ & {$[87]$} \\
\hline Lactate & Carbon paper & Geobacter SPP & Two-chamber & $52 \pm 4.7$ & {$[87]$} \\
\hline Ethanol & - & Betaproteobacteria & Two-chamber & $40 \pm 2$ & [89] \\
\hline Cysteine & Carbon paper & $\begin{array}{c}\text { Gammaproteobacteria and } \\
\text { Shewanella affinis (KMM3586) }\end{array}$ & Two-chamber & 36 & {$[30]$} \\
\hline $\begin{array}{l}\text { Marine sediment } \\
\text { reached in acetate }\end{array}$ & Graphite & Deltaproteobacteria & Two-chamber & 14 & {$[90]$} \\
\hline Marine sediment & Noncorroding graphite & Desulfuromonas spp. & Two-chamber & $25.4-26.6$ & [91] \\
\hline Sewage sludge & Graphite with $\mathrm{Mn}^{4+}$ & Escherichia coli & Single chamber & 91 & {$[92]$} \\
\hline Sewage sludge & $\begin{array}{l}\text { Graphite with neutral } \\
\text { red (NR) }\end{array}$ & Escherichia coli & Single chamber & 152 & {$[92]$} \\
\hline Sewage sludge & $\begin{array}{c}\text { Platinum and } \\
\text { polyanilineco-modified }\end{array}$ & Escherichia coli & Single chamber & 6000 & [93] \\
\hline Glucose & $\begin{array}{l}\text { Composite electrode } \\
\text { (graphite/PTFE) }\end{array}$ & Escherichia coli & Single chamber & 760 & {$[86]$} \\
\hline Glucose & $\begin{array}{l}\text { Teflon-treated carbon } \\
\text { fiber paper }\end{array}$ & Electrochemically active bacteria & $\begin{array}{l}\text { Two-chamber (H- } \\
\text { type MFC) }\end{array}$ & 15.2 & [94] \\
\hline Lactose & & “ & " & 17.2 & [95] \\
\hline Cellulose & $\begin{array}{l}\text { Nonwet proof carbon } \\
\text { paper }\end{array}$ & Cellulose-degrading bacteria & “ & 188 & [96] \\
\hline Glucose & Graphite plates & Mixed culture & $\begin{array}{l}\text { Two-chamber air- } \\
\text { cathode MFC }\end{array}$ & 283 & [97] \\
\hline Glucose & $\begin{array}{l}\text { Carbon paper with } \\
\text { PPY-CNTs }\end{array}$ & Escherichia coli & DCMFC & 228 & [98] \\
\hline
\end{tabular}

metabolism of microbe allows the removal of side products. Other than that, by dismissing the possibility of needing to use mediators of electrons at cathode and toxic Pt chamber, this will directly improve the sustainability of MFC [109]. There are two types of biocathodes, which are anaerobic and aerobic. For aerobic biocathodes, reduction of oxygen with simultaneous transition metal oxidation catalyzed with biofilm present on the cathode surface like $\mathrm{Mn}$ (II) and Fe (II) is possible. Furthermore, a larger power density can be obtained as compared to using anaerobic biocathodes [110]. Biocathode-based MFC is also capable of treating surplus streams of wastewater in the cathode. Besides, microbial metabolites will accumulate in the cathode compartment, which will obstruct the microbial activities; based on the report by Zhou et al. [111], removing various overpotentials, the resulting oxidation voltage of organic carbon and combination reaction of redox may be within minute value of the MFC.

The major limitation is the cathode performance. For an MFC to be of conventional use, cathode design is very crucial. Nonetheless, the power output for an MFC is independent of the cathode surface area, whereas the capability of the cathode can be increased with materials that have a large surface area or granular materials [112]. However, it is important and a challenge to recognize material that can increase and improve the electricity generation of an MFC to its fullest and reduce the cost at the same time. Carbon paper, brush, felt, and fiber, as well as many graphites, $\mathrm{Pt}$ which is also utilized as catalyst, $\mathrm{Cu}-\mathrm{Au}$, $\mathrm{Cu}$, granular graphite (great material), reticulated vitreous carbon (RVC), and tungsten carbide, have been used as cathode materials $[113,114]$. The characteristics of catalysts differ with cathode materials. Table 3 lists down the different values obtained with various heterogeneous cathode materials.

\section{Electrical Interaction between Electrodes- Bacterial Species}

In order to study the electrical interactions between pure and mixed cultures with anode of the system, cyclic voltammetry is frequently utilized as the process of indirect and direct transfer of electrons can be easily distinguished from that within biofilms connected to anode [119]. The use of cyclic voltammograms enables data interpretation of the process of electron transfer that differs according to the growth of the biofilm, the community of biofilm, and the energy produced by the biofilm $[120,121]$. However, interpretation through cyclic voltammograms can be quite difficult; for instance, for analysis of $G$. sulfurreducens using this technique, a lower rate of scans was used to increase the complexity and to raise the discernible systems redox from 2 to either 4 or more [49]. The cyclic voltammetry is capable of examining the nearest biofilm to the electrode; thus, the adequacy of this method to examine the large biofilm is questionable because of the notable gradient of potential that exists in biofilms [122]. This method is not suitable to work independently for physiochemical nature determination of mediators present in the transfer of electrons [123]. A lot of microorganisms such as Pseudomonas species, Geothrix fermentans, and 
TABLE 3: List of electrodes used in MFC with maximum power, voltage, and current produced.

\begin{tabular}{|c|c|c|c|c|}
\hline Cathode & Maximum PD & Maximum CD & Maximum voltage $(\mathrm{mV})$ & References \\
\hline Activated carbon fiber felt (ACFF) & $315 \mathrm{~mW} / \mathrm{m}^{2}\left(0.7 \mathrm{~W} / \mathrm{m}^{3}\right)$ & $1.67^{*} 10^{-3} \mathrm{~mA} / \mathrm{m}^{2}$ & 679 & [115] \\
\hline Air-cathode with graphite & $283 \mathrm{~mW} / \mathrm{m}^{2}$ & $1210 \mathrm{~mA} / \mathrm{m}^{2}$ & 440 & {$[97]$} \\
\hline Carbon felt & $77 \mathrm{~mW} / \mathrm{m}^{2}\left(0.2 \mathrm{~W} / \mathrm{m}^{3}\right)$ & $6^{*} 10^{-3} \mathrm{~mA} / \mathrm{m}^{2}$ & 575 & {$[115]$} \\
\hline Plain carbon & $67 \mathrm{~mW} / \mathrm{m}^{2}\left(0.1 \mathrm{~W} / \mathrm{m}^{3}\right)$ & $1.5 \mathrm{~mA} / \mathrm{m}^{2}$ & 598 & {$[115]$} \\
\hline Pt-coated carbon paper & $0.3 \mathrm{~W} / \mathrm{m}^{3}$ & $4.69 \mathrm{~mA} / \mathrm{m}^{2}$ & 644 & {$[115]$} \\
\hline Tubular ACFF & $784 \mathrm{~mW} / \mathrm{m}^{2}$ & $3.17 \mathrm{~A} / \mathrm{m}^{2}$ & 716 & [115] \\
\hline ACFF granules $(1 \mathrm{~cm})$ & $667 \mathrm{~W} / \mathrm{m}^{3}$ & $3.34 \mathrm{~A} / \mathrm{m}^{2}$ & 658 & {$[115]$} \\
\hline Biocathode & $19.53 \mathrm{~W} / \mathrm{m}^{3}$ & $41.78 \mathrm{~A} / \mathrm{m}^{3}$ & 432 & {$[20]$} \\
\hline Graphite felt & $539 \mathrm{~mW} / \mathrm{m}^{2}$ & $3145 \mathrm{~mA} / \mathrm{m}^{2}$ & 742.3 & {$[116]$} \\
\hline $\begin{array}{l}\text { Parallel sheets of carbon paper secured by } \\
\text { carbon fiber coated with } \mathrm{Pt}\end{array}$ & $7.29 \mathrm{~W} / \mathrm{m}^{3}$ & $13.16 \mathrm{~A} / \mathrm{m}^{3}$ & 553 & [117] \\
\hline Air-cathode with carbon cloth & $50 \mathrm{~W} / \mathrm{m}^{3}$ & $363 \mathrm{~A} / \mathrm{m}^{3}$ & 710 & {$[118]$} \\
\hline
\end{tabular}

Shewanella species have been recognized for mediators of electron formation, but applications in MFC that can generate high current have been debated in contrast to bacterial species that are capable of transferring electrons directly to electrode [123].

The processes of indirect and direct transfer of electrons and their possible mechanisms have been recognized through research of dissimilatory metal that can reduce bacteria using nonsoluble iron oxides as the terminal acceptor of electrons [124]. Identified routes for the movement of electrons, including shuttles of electron formation, direct contact of the external surface of c-type cytochromes, and long-distance contact through nanowires or electrically conductive pili. Various reviews have discussed the benefits of direct transfer of electron and pili application in the synthesis of conductive biofilm for shuttles formation [125]. G. sulfurreducens is the most frequently researched bacteria in MFC that can generate high-range densities of current. It represents the Geobacter communities to explain the processes involving bacterial species in the MFC system with environmental inoculum [126]. Other than that, pure cultures of this organism are capable of generating power that is close to or larger than the maximum for biofilm of mixedspecies biofilms. The sequence of the full genome can be obtained and modification of gene is possible, the analysis of the full microarray genome can also be obtained, and lastly, the availability of metabolic model of in silico based from the genome [127]. Moreover, G. sulfurreducens is classified as bacteria called electricigens capable of saving energy for development through complete oxidation of organic material to $\mathrm{CO}_{2}$ along with transfer of electrons directly to MFC anode [106]. Other names that refer to bacteria that can facilitate electron transfer have been suggested, such as exoelectrogens, anode-respiring bacteria, anodophilic bacteria, electrochemically active bacteria (EAB), and electrogenic microorganisms [128]. Electron transfer to electrode allows organic material to be completely oxidized and, as a result, produces a large value of Coulombic efficiency; bacteria species facilitate direct transfer of electron towards anode removing the requirement of exogenous and electrons mediator's formation; lasting stability related to the ability of energy conservation for development due to electron transfer capability is one of the strong points of the utilization of electricigens in MFC [105]. The bacteria-anode interaction is systematically shown in Figure 2.

Indication of direct contact between anode and cells through interaction via c-type cytochromes on the external layers is recognized by analysis of electrochemical and expression of genome-scale gene [130]. The thickness of biofilms formed from G. sulfurreducens is more than $50 \mu \mathrm{m}$ and the cells are active metabolically and facilitate the generation of energy [131]. The investigation of the expression of genes proposed that for the long-distance transfer of electrons via the biofilms of G. sulfurreducens, it is crucial to form microbial nanowires [132]. Formation of the high value of current is also anticipated by representative studies via biofilm of thick anode if the conductive biofilm is present [133]. The generation of biofilm that is conductive is unlikely because the majority function as insulators [134]. In the field of MFC, it will be a great discovery to explore the conductivity determination, measurement, and the materials that affect the biofilm conductivity.

The focus that energy is gained by bacterial species for the electrode or shuttle of electrons directly is a common misunderstanding. In actuality, energy is received from the activities of protons pumping over the internal membrane that produces a gradient of protons that enhances the production of ATP via ATPase from ADP. In this regard, the external transfer of electron function is to migrate the electron towards the surface of anode, but no energy is obtained during the process for the growth of bacteria; instead, the proton gradient enables the formation of ATP, which in return supplies energy for the bacterial species [135].

The effort has been made to enhance the generation of current by genetic engineering but is unsuccessful [136]. The power generated does not increase, albeit there is an excess of microbial nanowires or cytochromes; similarly, ATP drain formation as forecasted by metabolism representative to raise the metabolic activity also did not have any effect on the current. Based on these investigations, it is clear that the production of current in an MFC is a difficult process that needs more than a few gene modifications or rates of bacterial respiration to have an impact on the current rate of generation. Adaptive selection has shown more positive results in strain production to increase the density of current 


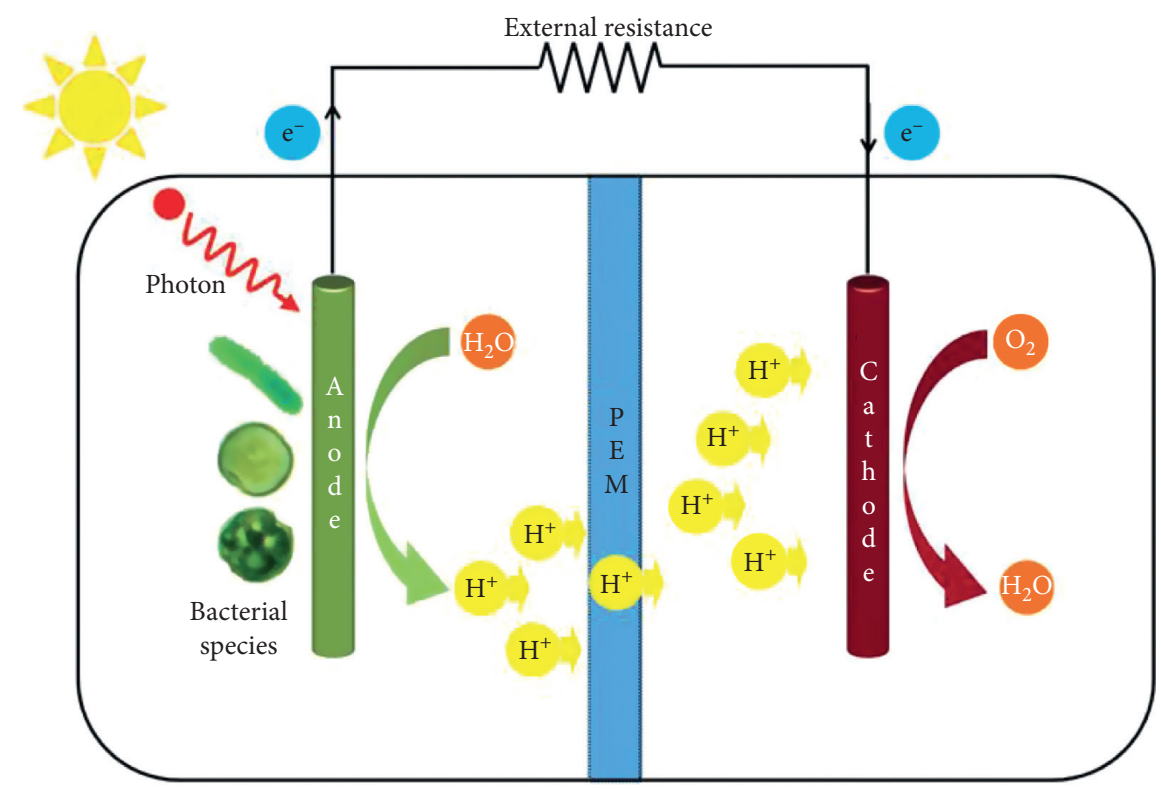

Figure 2: A dual-chamber PMFC with photosynthetic microorganisms serving as electricigens in the anodic chamber is shown schematically (adapted from [129] with Springer Nature Open Access Permission).

in MFC. One example is MFC with a low operating potential that was deployed for a period of more than 5 months and resulted in the separation of a $G$. sulfurreducens variant called KN400 that allows the rise in power density up to 8 times. The strain formed generates biofilm that is thinner along with cytochromes of small external surface area but a large number of nanowires that may enable the examination of the transfer of electrons occurring at increased current densities.

\section{MFC Commercialization and Future Perspectives}

The commercialization of technology can be deemed successful if more people become aware of the product and it is marketed in large amounts to a wide range of consumers. The commercialization of MFC will bring more benefits due to its function in energy production through the utilization of wastes. For instance, electricity can easily be generated at homes; energy generation with low expense can be accomplished all year long as waste materials. The xenobiotics are abundant in low-income countries like Africa; the MFC will be beneficial because of its low operating cost as compared to large foundations needed to set up energy generation plants that are unavailable [137]. Lastly, MFC could be an alternative for the remediation process to remove hazardous substances from xenobiotics and wastes [138]. The performance of an MFC technology is dependent on the number of variables used to observe the system, for example, the utilized substrates, the setup, microbes present, catalyst, concentration, ideal membrane, and electrode materials. A large number of accessible reports have shown that MFC could be configured from sizes of a few milliliters to a few thousand liters. Based on these reports, the outcome is that the power generated is affected by the MFC scaling, which is a major weakness in marketing MFC. The space between anode and cathode is one of the components that can affect the power production for MFC [139]. With bigger cell size, the size of electrodes used will also increase; however, the separation itself does not change to the same extent to avoid bulky cells and this causes the low generation of power. Another reason that limits MFC scaling is the price of electrodes, which rationally should be inexpensive, but as the electrodes are bought instead of being produced in the industry, the price becomes higher, as well as because of the material itself. The membrane present in MFC is also created using high-cost material such as nylon. Substrates also play an important role for MFC and depending on the type of substrate utilized, the power output will differ. As an example, the pure substrate will result in high power production, but by using wastes as substrates, the value of power generated decreased significantly. The reason for this is that microorganisms are incapable of metabolizing waste and pure sources of carbon [140]. These are some of the limiting factors towards MFC commercialization. MFC is capable of utilizing various organic materials in producing energy. Nevertheless, MFC still has few weaknesses that need to be addressed in order for the technology to be applied in a practical situation. The biggest challenge of an MFC is the poor density of power, which can be sorted out either by separating strong microbes that are capable of transferring electrons towards anode or by synthesizing engineered strains via DNA recombination that provides a higher transfer rate of electrons. Various consortia of bacteria are proven to be more efficient in transferring electrons than pure cultures and more strains of bacteria can generate mediators for a more successful electron transfer. New types of mediators are recognized to enhance MFC performance. The small surface area of an MFC is also a big challenge as a limited number of microorganisms can adhere to it. Further 
studies reported new techniques that can improve the performance of MFC, which provide a more efficient configuration of small-scale MFC. Some of the techniques are stacked reactors, assemblies of cloth electrodes, and utilization of air cathodes. Utilization of air-cathode MFC is the most efficient method out of all techniques because it utilizes oxygen sources from air efficiently, in return removing the requirement of water aeration and employing chemical catholytes like ferricyanide that need to be regenerated. Distinct cell designs are used in evaluating the consequences of utilizing various shapes and positions for MFC improvement and optimization of air-cathode is also done for MFC utilization. Great results have been achieved through these attempts in which a power output of more than $1000 \mathrm{~W} \mathrm{~m}^{3}$ was generated from an efficient small-scale MFC $(\sim 20 \mathrm{ml}$ volume of anode) [141]. Nevertheless, producing a large-size MFC that can provide increased energy generation and performance stability is still a difficult task. According to a study done by Liu et al. [142], the highest value of power density $20 \mathrm{~W} \mathrm{~m}^{3}$ can be achieved by using MFC of $500 \mathrm{ml}$ in volume. The final downside of the MFC system is in regard to wastewater treatment and MFC scaling up. These are crucial issues needing solutions as scaling up can result in MFC application for a large-scale setup that can help in thoroughly improving MFC performance, especially in the case of wastewater treatment that is abundant.

\section{Conclusion}

Electricity generation through the MFC system by utilizing organic substrates that are oxidized by bacterial species can provide a promising technique for the future. In this review, major waste materials such as acetate, brewery wastewater, synthetic wastewater, inorganic compounds, and azo dyes, which are harmful to the environment and living beings, have been discussed, which can explore new potential through electricity generation via MFC as substrates. In addition, some of the toxic substances can also be treated and converted into less harmful substances that are beneficial for the management of waste and can decrease the amount of environmental pollution. Until recently, a wide range of substrates had been used in MFC for energy production. Even so, major challenges for practical use of MFC need to be addressed and solved, such as the poor output of power and reduction of energy production as a result of scaling up. These factors contribute to difficulties in MFC commercialization. Thus, more efforts are needed to provide a feasible, applicable, and efficient technology that can be approved and acknowledged by the industry.

\section{Data Availability}

No data were used to support this study.

\section{Conflicts of Interest}

The authors declare that they have no conflicts of interest.

\section{Acknowledgments}

This article was financially supported by Open University of Sudan.

\section{References}

[1] T. Kåberger, "Progress of renewable electricity replacing fossil fuels," Global Energy Interconnection, vol. 1, pp. 48-52, 2018.

[2] A. A. Yaqoob, N. H. b. M. Noor, K. Umar, R. Adnan, M. N. M. Ibrahim, and M. Rashid, "Graphene oxide- $\mathrm{ZnO}$ nanocomposite: an efficient visible light photocatalyst for degradation of rhodamine B," Applied Nanoscience, vol. 11, no. 4, pp. 1291-1302, 2021.

[3] I. Hanif, B. Aziz, and I. S. Chaudhry, "Carbon emissions across the spectrum of renewable and nonrenewable energy use in developing economies of Asia," Renewable Energy, vol. 143, pp. 586-595, 2019.

[4] A. A. Yaqoob, T. Parveen, K. Umar, and M. N. Mohamad Ibrahim, "Role of nanomaterials in the treatment of wastewater: a review," Water, vol. 12, no. 2, p. 495, 2020.

[5] A. Shahsavari and M. Akbari, "Potential of solar energy in developing countries for reducing energy-related emissions," Renewable and Sustainable Energy Reviews, vol. 90, pp. 275-291, 2018.

[6] A. Y. Asim, M. N. M. Ibrahim, U. Khalid et al., "A glimpse into the microbial fuel cells for wastewater treatment with energy generation," Desalination and Water Treatment, vol. 214, pp. 379-389, 2021.

[7] N. Kannan and D. Vakeesan, "Solar energy for future world: a review," Renewable and Sustainable Energy Reviews, vol. 62, pp. 1092-1105, 2016.

[8] S. J. Peighambardoust, S. Rowshanzamir, and M. Amjadi, "Review of the proton exchange membranes for fuel cell applications," International Journal of Hydrogen Energy, vol. 35, no. 17, pp. 9349-9384, 2010.

[9] B. E. Logan, B. Hamelers, R. Rozendal et al., "Microbial fuel cells: methodology and technology," Environmental Science \& Technology, vol. 40, no. 17, pp. 5181-5192, 2006.

[10] F. S. Fadzli, M. Rashid, A. A. Yaqoob, and M. N. Mohamad Ibrahim, "Electricity generation and heavy metal remediation by utilizing yam (Dioscorea alata) waste in benthic microbial fuel cells (BMFCs)," Biochemical Engineering Journal, vol. 172, Article ID 108067, 2021.

[11] M. C. Potter, "Electrical effects accompanying the decomposition of organic compounds," Proceedings of the Royal Society of London. Series B, Containing Papers of a Biological Character, vol. 84, no. 571, pp. 260-276, 1911.

[12] K. Lewis, "Symposium on bioelectrochemistry of microorganisms. IV. Biochemical fuel cells," Bacteriological Reviews, vol. 30, no. 1, pp. 101-113, 1966.

[13] R. M. Allen and H. P. Bennetto, "Microbial fuel-cells," Applied Biochemistry and Biotechnology, vol. 39-40, no. 1, pp. 27-40, 1993.

[14] H. J. Kim, S. H. MOON, and H. K. BYUNG, "A microbial fuel cell type lactate biosensor using a metal-reducing bacterium, Shewanella putrefaciens," Journal of Microbiology and Biotechnology, vol. 9, pp. 365-367, 1999.

[15] M. F. Umar, S. Z. Abbas, M. N. Mohamad Ibrahim, N. Ismail, and M. Rafatullah, "Insights into advancements and electrons transfer mechanisms of electrogens in benthic microbial fuel cells," Membranes, vol. 10, no. 9, p. 205, 2020. 
[16] A. A. Yaqoob, A. Khatoon, S. H. Mohd Setapar et al., "Outlook on the role of microbial fuel cells in remediation of environmental pollutants with electricity generation," Catalysts, vol. 10, no. 8, p. 819, 2020.

[17] A. A. Yaqoob, M. N. Mohamad Ibrahim, M. Rafatullah, Y. S. Chua, A. Ahmad, and K. Umar, "Recent advances in anodes for microbial fuel cells: an overview," Materials, vol. 13, no. 9, p. 2078, 2020.

[18] G.-W. Chen, S.-J. Choi, T.-H. Lee, G.-Y. Lee, J.-H. Cha, and C.-W. Kim, "Application of biocathode in microbial fuel cells: cell performance and microbial community," Applied Microbiology and Biotechnology, vol. 79, no. 3, pp. 379-388, 2008.

[19] A. A. Yaqoob, M. N. M. Ibrahim, and S. Rodríguez-Couto, "Development and modification of materials to build costeffective anodes for microbial fuel cells (MFCs): an overview," Biochemical Engineering Journal, vol. 164, Article ID 107779, 2020.

[20] Y. Sharma and B. Li, "The variation of power generation with organic substrates in single-chamber microbial fuel cells (SCMFCs)," Bioresource Technology, vol. 101, no. 6, pp. 1844-1850, 2010.

[21] M. Rahimnejad, A. Adhami, S. Darvari, A. Zirepour, and S.-E. Oh, "Microbial fuel cell as new technology for bioelectricity generation: a review," Alexandria Engineering Journal, vol. 54, no. 3, pp. 745-756, 2015.

[22] D. Pant, G. Van Bogaert, L. Diels, and K. Vanbroekhoven, "A review of the substrates used in microbial fuel cells (MFCs) for sustainable energy production," Bioresource Technology, vol. 101, no. 6, pp. 1533-1543, 2010.

[23] A. A. Yaqoob, M. N. Mohamad Ibrahim, K. Umar et al., "Cellulose derived graphene/polyaniline nanocomposite anode for energy generation and bioremediation of toxic metals via benthic microbial fuel cells," Polymers, vol. 13, no. 1, p. 135, 2021.

[24] R. Kleerebezem and M. C. van Loosdrecht, "Mixed culture biotechnology for bioenergy production," Current Opinion in Biotechnology, vol. 18, no. 3, pp. 207-212, 2007.

[25] B. Logan, S. Cheng, V. Watson, and G. Estadt, "Graphite fiber brush anodes for increased power production in aircathode microbial fuel cells," Environmental Science \& Technology, vol. 41, no. 9, pp. 3341-3346, 2007.

[26] T. Catal, S. Xu, K. Li, H. Bermek, and H. Liu, "Electricity generation from polyalcohols in single-chamber microbial fuel cells," Biosensors and Bioelectronics, vol. 24, no. 4, pp. 849-854, 2008.

[27] J. Sun, Y.-y. Hu, Z. Bi, and Y.-q. Cao, "Simultaneous decolorization of azo dye and bioelectricity generation using a microfiltration membrane air-cathode single-chamber microbial fuel cell," Bioresource Technology, vol. 100, no. 13, pp. 3185-3192, 2009.

[28] Z. Ren, L. M. Steinberg, and J. M. Regan, "Electricity production and microbial biofilm characterization in cellulosefed microbial fuel cells," Water Science and Technology, vol. 58, no. 3, pp. 617-622, 2008.

[29] Y. Zuo, P.-C. Maness, and B. E. Logan, "Electricity production from steam-exploded corn stover biomass," Energy \& Fuels, vol. 20, no. 4, pp. 1716-1721, 2006.

[30] B. E. Logan, C. Murano, K. Scott, N. D. Gray, and I. M. Head, "Electricity generation from cysteine in a microbial fuel cell," Water Research, vol. 39, no. 5, pp. 942-952, 2005.

[31] H. Pham, N. Boon, M. Marzorati, and W. Verstraete, "Enhanced removal of 1,2-dichloroethane by anodophilic microbial consortia," Water Research, vol. 43, no. 11, pp. 2936-2946, 2009.

[32] Y. Luo, G. Liu, R. Zhang, and C. Zhang, "Power generation from furfural using the microbial fuel cell," Journal of Power Sources, vol. 195, no. 1, pp. 190-194, 2010.

[33] T. Catal, K. Li, H. Bermek, and H. Liu, "Electricity production from twelve monosaccharides using microbial fuel cells," Journal of Power Sources, vol. 175, no. 1, pp. 196-200, 2008.

[34] A. K. Manohar and F. Mansfeld, "The internal resistance of a microbial fuel cell and its dependence on cell design and operating conditions," Electrochimica Acta, vol. 54, no. 6, pp. 1664-1670, 2009.

[35] J. Greenman, A. Gálvez, L. Giusti, and I. Ieropoulos, "Electricity from landfill leachate using microbial fuel cells: comparison with a biological aerated filter," Enzyme and Microbial Technology, vol. 44, no. 2, pp. 112-119, 2009.

[36] S. Venkata Mohan, G. Mohanakrishna, B. P. Reddy, R. Saravanan, and P. N. Sarma, "Bioelectricity generation from chemical wastewater treatment in mediatorless (anode) microbial fuel cell (MFC) using selectively enriched hydrogen producing mixed culture under acidophilic microenvironment," Biochemical Engineering Journal, vol. 39, no. 1, pp. 121-130, 2008.

[37] S. Venkata Mohan, R. Saravanan, S. V. Raghavulu, G. Mohanakrishna, and P. N. Sarma, "Bioelectricity production from wastewater treatment in dual chambered microbial fuel cell (MFC) using selectively enriched mixed microflora: effect of catholyte," Bioresource Technology, vol. 99, no. 3, pp. 596-603, 2008.

[38] C. Dumas, R. Basseguy, and A. Bergel, "Microbial electrocatalysis with Geobacter sulfurreducens biofilm on stainless steel cathodes," Electrochimica Acta, vol. 53, no. 5, pp. 2494-2500, 2008.

[39] M. Behera and M. M. Ghangrekar, "Performance of microbial fuel cell in response to change in sludge loading rate at different anodic feed pH," Bioresource Technology, vol. 100, no. 21, pp. 5114-5121, 2009.

[40] L. Huang and I. Angelidaki, "Effect of humic acids on electricity generation integrated with xylose degradation in microbial fuel cells," Biotechnology and Bioengineering, vol. 100, no. 3, pp. 413-422, 2008.

[41] Q. Wen, Y. Wu, D. Cao, L. Zhao, and Q. Sun, "Electricity generation and modeling of microbial fuel cell from continuous beer brewery wastewater," Bioresource Technology, vol. 100, no. 18, pp. 4171-4175, 2009.

[42] S. A. Patil, V. P. Surakasi, S. Koul et al., "Electricity generation using chocolate industry wastewater and its treatment in activated sludge based microbial fuel cell and analysis of developed microbial community in the anode chamber," Bioresource Technology, vol. 100, no. 21, pp. 5132-5139, 2009.

[43] X. Wang, Y. Feng, N. Ren et al., "Accelerated start-up of twochambered microbial fuel cells: effect of anodic positive poised potential," Electrochimica Acta, vol. 54, no. 3, pp. 1109-1114, 2009.

[44] Z. Liu, J. Liu, S. Zhang, and Z. Su, "Study of operational performance and electrical response on mediator-less microbial fuel cells fed with carbon- and protein-rich substrates," Biochemical Engineering Journal, vol. 45, no. 3, pp. 185-191, 2009.

[45] M. A. Rodrigo, P. Cañizares, H. García, J. J. Linares, and J. Lobato, "Study of the acclimation stage and of the effect of the biodegradability on the performance of a microbial fuel 
cell," Bioresource Technology, vol. 100, no. 20, pp. 4704-4710, 2009.

[46] A. Aldrovandi, E. Marsili, L. Stante, P. Paganin, S. Tabacchioni, and A. Giordano, "Sustainable power production in a membrane-less and mediator-less synthetic wastewater microbial fuel cell," Bioresource Technology, vol. 100, no. 13, pp. 3252-3260, 2009.

[47] S. B. Pasupuleti, S. Srikanth, X. Dominguez-Benetton, S. V. Mohan, and D. Pant, "Dual gas diffusion cathode design for microbial fuel cell (MFC): optimizing the suitable mode of operation in terms of bioelectrochemical and bioelectrokinetic evaluation," Journal of Chemical Technology \& Biotechnology, vol. 91, no. 3, pp. 624-639, 2016.

[48] J. C. Biffinger, J. N. Byrd, B. L. Dudley, and B. R. Ringeisen, "Oxygen exposure promotes fuel diversity for Shewanella oneidensis microbial fuel cells," Biosensors and Bioelectronics, vol. 23, no. 6, pp. 820-826, 2008.

[49] H. Liu, S. Cheng, and B. E. Logan, "Production of electricity from acetate or butyrate using a single-chamber microbial fuel cell," Environmental Science \& Technology, vol. 39, no. 2, pp. 658-662, 2005.

[50] K.-J. Chae, M.-J. Choi, J.-W. Lee, K.-Y. Kim, and I. S. Kim, "Effect of different substrates on the performance, bacterial diversity, and bacterial viability in microbial fuel cells," Bioresource Technology, vol. 100, no. 14, pp. 3518-3525, 2009.

[51] N. Kim, Y. Choi, S. Jung, and S. Kim, "Effect of initial carbon sources on the performance of microbial fuel cells containing Proteus vulgaris," Biotechnology and Bioengineering, vol. 70, no. 1, pp. 109-114, 2000.

[52] K. Rabaey, G. Lissens, S. D. Siciliano, and W. Verstraete, "A microbial fuel cell capable of converting glucose to electricity at high rate and efficiency," Biotechnology Letters, vol. 25, no. 18 , pp. $1531-1535,2003$

[53] Z. Hu, "Electricity generation by a baffle-chamber membraneless microbial fuel cell," Journal of Power Sources, vol. 179, no. 1, pp. 27-33, 2008.

[54] H.-S. Lee, P. Parameswaran, A. Kato-Marcus, C. I. Torres, and B. E. Rittmann, "Evaluation of energy-conversion efficiencies in microbial fuel cells (MFCs) utilizing fermentable and non-fermentable substrates," Water Research, vol. 42, no. 6-7, pp. 1501-1510, 2008.

[55] A. A. Yaqoob, M. N. M. Ibrahim, A. S. Yaakop, and A. Ahmad, "Application of microbial fuel cells energized by oil palm trunk sap (OPTS) to remove the toxic metal from synthetic wastewater with generation of electricity," Applied Nanoscience, vol. 20, pp. 1-13, 2021.

[56] A. A. Yaqoob, A. Serrà, M. N. M. Ibrahim, and A. S. Yaakop, "Self-assembled oil palm biomass-derived modified graphene oxide anode: an efficient medium for energy transportation and bioremediating Cd (II) via microbial fuel cells," Arabian Journal of Chemistry, vol. 14, no. 5, Article ID 103121, 2021.

[57] K. Kucharska, P. Rybarczyk, I. Hołowacz, R. Łukajtis, M. Glinka, and M. Kamiński, "Pretreatment of lignocellulosic materials as substrates for fermentation processes," Molecules, vol. 23, no. 11, p. 2937, 2018.

[58] P. Pandey, V. N. Shinde, R. L. Deopurkar, S. P. Kale, S. A. Patil, and D. Pant, "Recent advances in the use of different substrates in microbial fuel cells toward wastewater treatment and simultaneous energy recovery," Applied Energy, vol. 168, pp. 706-723, 2016.

[59] S. S. Kumar, V. Kumar, R. Kumar, S. K. Malyan, and A. Pugazhendhi, "Microbial fuel cells as a sustainable platform technology for bioenergy, biosensing, environmental monitoring, and other low power device applications," Fuel, vol. 255, Article ID 115682, 2019.

[60] W. Miran, M. Nawaz, A. Kadam et al., "Microbial community structure in a dual chamber microbial fuel cell fed with brewery waste for azo dye degradation and electricity generation," Environmental Science and Pollution Research, vol. 22, no. 17, pp. 13477-13485, 2015.

[61] K. Vijayaraghavan, D. Ahmad, and R. Lesa, "Electrolytic treatment of beer brewery wastewater," Industrial \& Engineering Chemistry Research, vol. 45, no. 20, pp. 6854-6859, 2006.

[62] Y. Feng, X. Wang, B. E. Logan, and H. Lee, "Brewery wastewater treatment using air-cathode microbial fuel cells," Applied Microbiology and Biotechnology, vol. 78, no. 5, pp. 873-880, 2008.

[63] S. Khalid, F. Alvi, M. Fatima et al., "Dye degradation and electricity generation using microbial fuel cell with graphene oxide modified anode," Materials Letters, vol. 220, pp. 272-276, 2018.

[64] X. Cao, H. Wang, X.-q. Li, Z. Fang, and X.-n. Li, "Enhanced degradation of azo dye by a stacked microbial fuel cellbiofilm electrode reactor coupled system," Bioresource Technology, vol. 227, pp. 273-278, 2017.

[65] K. Rabaey, K. Van de Sompel, L. Maignien et al., "Microbial fuel cells for sulfide removal," Environmental Science \& Technology, vol. 40, no. 17, pp. 5218-5224, 2006.

[66] L. Huang and B. E. Logan, "Electricity generation and treatment of paper recycling wastewater using a microbial fuel cell," Applied Microbiology and Biotechnology, vol. 80, no. 2, pp. 349-355, 2008.

[67] H. Luo, G. Liu, R. Zhang, and S. Jin, "Phenol degradation in microbial fuel cells," Chemical Engineering Journal, vol. 147, no. 2-3, pp. 259-264, 2009.

[68] P. Kaparaju, M. Serrano, A. B. Thomsen, P. Kongjan, and I. Angelidaki, "Bioethanol, biohydrogen and biogas production from wheat straw in a biorefinery concept," Bioresource Technology, vol. 100, no. 9, pp. 2562-2568, 2009.

[69] A. P. Borole, J. R. Mielenz, T. A. Vishnivetskaya, and C. Y. Hamilton, "Controlling accumulation of fermentation inhibitors in biorefinery recycle water using microbial fuel cells," Biotechnology for Biofuels, vol. 2, pp. 1-14, 2009.

[70] D. Kim and I. S. Chang, "Electricity generation from synthesis gas by microbial processes: $\mathrm{CO}$ fermentation and microbial fuel cell technology," Bioresource Technology, vol. 100, no. 19, pp. 4527-4530, 2009.

[71] F. Zhao, N. Rahunen, J. R. Varcoe et al., "Factors affecting the performance of microbial fuel cells for sulfur pollutants removal," Biosensors and Bioelectronics, vol. 24, no. 7, pp. 1931-1936, 2009.

[72] M. Rahimnejad, G. Mostafa, N. Ghasem et al., "Acetone removal and bioelectricity generation in dual chamber Microbial Fuel Cell," American Journal of Biochemistry and Biotechnology, vol. 8, pp. 304-310, 2012.

[73] S. G. Peera, T. Maiyalagan, C. Liu et al., "A review on carbon and non-precious metal based cathode catalysts in microbial fuel cells," International Journal of Hydrogen Energy, vol. 46, no. 4, pp. 3056-3089, 2021.

[74] S. Xin, J. Shen, G. Liu et al., "Electricity generation and microbial community of single-chamber microbial fuel cells in response to $\mathrm{Cu} 2 \mathrm{O}$ nanoparticles/reduced graphene oxide as cathode catalyst," Chemical Engineering Journal, vol. 380, Article ID 122446, 2020. 
[75] A. A. Yaqoob, M. N. M. Ibrahim, and C. Guerrero-Barajas, "Modern trend of anodes in microbial fuel cells (MFCs): an overview," Environmental Technology \& Innovation, vol. 23, Article ID 101579, 2021

[76] A. A. Yaqoob, M. N. M. Ibrahim, A. S. Yaakop, K. Umar, and A. Ahmad, "Modified graphene oxide anode: a bioinspired waste material for bioremediation of $\mathrm{Pb} 2+$ with energy generation through microbial fuel cells," Chemical Engineering Journal, vol. 417, Article ID 128052, 2020.

[77] J. Wei, P. Liang, and X. Huang, "Recent progress in electrodes for microbial fuel cells," Bioresource Technology, vol. 102, no. 20, pp. 9335-9344, 2011.

[78] A. A. Yaqoob, M. N. M. Ibrahim, A. Ahmad, and A. Vijaya Bhaskar Reddy, "Toxicology and environmental application of carbon nanocomposite," Environmental Remediation through Carbon Based Nano Composites, Springer, Berlin, Germany, pp. 1-18, 2021.

[79] M. Zhou, M. Chi, J. Luo, H. He, and T. Jin, "An overview of electrode materials in microbial fuel cells," Journal of Power Sources, vol. 196, no. 10, pp. 4427-4435, 2011.

[80] Y. Qiao, C. M. Li, S.-J. Bao, and Q.-L. Bao, "Carbon nanotube/polyaniline composite as anode material for microbial fuel cells," Journal of Power Sources, vol. 170, no. 1, pp. 79-84, 2007.

[81] S. Narayanasamy and J. Jayaprakash, "Application of carbonpolymer based composite electrodes for microbial fuel cells," Reviews in Environmental Science and Bio/Technology, vol. 19, no. 3, pp. 595-620, 2020.

[82] K. Umar, A. Yaqoob, M. Ibrahim, T. Parveen, and M. Safian, "Environmental applications of smart polymer composites," Smart Polymer Nanocomposites, vol. 15, pp. 295-320, 2020.

[83] M. Yellappa, J. Annie Modestra, Y. V. Rami Reddy, and S. Venkata Mohan, "Functionalized conductive activated carbon-polyaniline composite anode for augmented energy recovery in microbial fuel cells," Bioresource Technology, vol. 320, Article ID 124340, 2021.

[84] A. G. Olabi, T. Wilberforce, E. T. Sayed, K. Elsaid, H. Rezk, and M. A. Abdelkareem, "Recent progress of graphene based nanomaterials in bioelectrochemical systems," Science of The Total Environment, vol. 749, Article ID 141225, 2020.

[85] A. A. Yaqoob, H. Ahmad, T. Parveen et al., "Recent advances in metal decorated nanomaterials and their various biological applications: a review," Frontiers in Chemistry, vol. 8, p. 341, 2020.

[86] T. Zhang, Y. Zeng, S. Chen, X. Ai, and H. Yang, "Improved performances of E. coli-catalyzed microbial fuel cells with composite graphite/PTFE anodes," Electrochemistry Communications, vol. 9, no. 3, pp. 349-353, 2007.

[87] S. Jung and J. M. Regan, "Comparison of anode bacterial communities and performance in microbial fuel cells with different electron donors," Applied Microbiology and Biotechnology, vol. 77, no. 2, pp. 393-402, 2007.

[88] M. Rahimnejad, N. Mokhtarian, G. Najafpour, W. Daud, and A. Ghoreyshi, "Low voltage power generation in a biofuel cell using anaerobic cultures," World Applied Sciences Journal, vol. 6, pp. 1585-1588, 2009.

[89] J. Kim, S. Jung, J. Regan, and B. Logan, "Electricity generation and microbial community analysis of alcohol powered microbial fuel cells," Bioresource Technology, vol. 98, no. 13, pp. 2568-2577, 2007.

[90] M. Zhou, J. Yang, H. Wang, T. Jin, D. J. Hassett, and T. Gu, "Bioelectrochemistry of microbial fuel cells and their potential applications in bioenergy," Bioenergy Research: Advances and Applications, pp. 131-152, 2014.

[91] G.-C. Gil, I.-S. Chang, B. H. Kim et al., "Operational parameters affecting the performance of a mediator-less microbial fuel cell," Biosensors and Bioelectronics, vol. 18, no. 4, pp. 327-334, 2003.

[92] K. P. Nevin, H. Richter, S. F. Covalla et al., "Power output and columbic efficiencies from biofilms of Geobacter sulfurreducens comparable to mixed community microbial fuel cells," Environmental Microbiology, vol. 10, no. 10, pp. 2505-2514, 2008.

[93] A. E. Franks and K. P. Nevin, "Microbial fuel cells, a current review," Energies, vol. 3, no. 5, pp. 899-919, 2010.

[94] G. Antonopoulou, K. Stamatelatou, S. Bebelis, and G. Lyberatos, "Electricity generation from synthetic substrates and cheese whey using a two chamber microbial fuel cell," Biochemical Engineering Journal, vol. 50, no. 1-2, pp. 10-15, 2010.

[95] M. Rahimnejad, G. Najafpour, and A. A. Ghoreyshi, "Effect of mass transfer on performance of microbial fuel cell," Intech, vol. 5, pp. 233-250, 2011.

[96] B. E. Logan and J. M. Regan, Microbial Fuel Cells-Challenges and Applications, ACS Publications, Washington, DC, USA, 2006.

[97] M. Rahimnejad, A. A. Ghoreyshi, G. Najafpour, and T. Jafary, "Power generation from organic substrate in batch and continuous flow microbial fuel cell operations," Applied Energy, vol. 88, no. 11, pp. 3999-4004, 2011.

[98] Y. Zou, C. Xiang, L. Yang, L.-X. Sun, F. Xu, and Z. Cao, “A mediatorless microbial fuel cell using polypyrrole coated carbon nanotubes composite as anode material," International Journal of Hydrogen Energy, vol. 33, no. 18, pp. 4856-4862, 2008.

[99] C. Bettin, Applicability and Feasibility of Incorporating Microbial Fuel Cell Technology into Implantable Biomedical Devices, The Ohio State University, Columbus, OH, USA, 2006.

[100] S. Wu, Y. Qiao, K. Jiang, Y. He, S. Guo, and H. Zhou, "Tailoring sodium anodes for stable sodium-oxygen batteries," Advanced Functional Materials, vol. 28, no. 13, Article ID 1706374, 2018.

[101] S. Wang, F. Ichihara, H. Pang, H. Chen, and J. Ye, "Nitrogen fixation reaction derived from nanostructured catalytic materials," Advanced Functional Materials, vol. 28, no. 50, Article ID 1803309, 2018.

[102] M. Sajid, X. Zhao, and D. Liu, "Production of 2,5-furandicarboxylic acid (FDCA) from 5-hydroxymethylfurfural (HMF): recent progress focusing on the chemical-catalytic routes," Green Chemistry, vol. 20, no. 24, pp. 5427-5453, 2018.

[103] E. Martin, B. Tartakovsky, and O. Savadogo, "Cathode materials evaluation in microbial fuel cells: a comparison of carbon, $\mathrm{Mn} 2 \mathrm{O} 3, \mathrm{Fe} 2 \mathrm{O} 3$ and platinum materials," Electrochimica Acta, vol. 58, pp. 58-66, 2011.

[104] I. S. Chang, H. Moon, J. K. Jang, and B. H. Kim, "Improvement of a microbial fuel cell performance as a BOD sensor using respiratory inhibitors," Biosensors and Bioelectronics, vol. 20, no. 9, pp. 1856-1859, 2005.

[105] G. Najafpour, M. Rahimnejad, and A. Ghoreshi, "The enhancement of a microbial fuel cell for electrical output using mediators and oxidizing agents," Energy Sources, Part A: Recovery, Utilization, and Environmental Effects, vol. 33, no. 24, pp. 2239-2248, 2011. 
[106] O. Lefebvre, W. K. Ooi, Z. Tang, M. Abdullah-Al-Mamun, D. H. C. Chua, and H. Y. Ng, "Optimization of a Pt-free cathode suitable for practical applications of microbial fuel cells," Bioresource Technology, vol. 100, no. 20, pp. 4907-4910, 2009.

[107] L. Huang, J. M. Regan, and X. Quan, "Electron transfer mechanisms, new applications, and performance of biocathode microbial fuel cells," Bioresource Technology, vol. 102, no. 1, pp. 316-323, 2011.

[108] M. Rahimnejad, G. D. Najafpour, A. A. Ghoreyshi et al., "Thionine increases electricity generation from microbial fuel cell using Saccharomyces cerevisiae and exoelectrogenic mixed culture," Journal of Microbiology, vol. 50, no. 4, pp. 575-580, 2012.

[109] Z. He and L. T. Angenent, "Application of bacterial biocathodes in microbial fuel cells," Electroanalysis, vol. 18, no. 19-20, pp. 2009-2015, 2006.

[110] S. Srikanth and S. Venkata Mohan, "Change in electrogenic activity of the microbial fuel cell (MFC) with the function of biocathode microenvironment as terminal electron accepting condition: influence on overpotentials and bio-electro kinetics," Bioresource Technology, vol. 119, pp. 241-251, 2012.

[111] M. Zhou, H. Wang, D. J. Hassett, and T. Gu, "Recent advances in microbial fuel cells (MFCs) and microbial electrolysis cells (MECs) for wastewater treatment, bioenergy and bioproducts," Journal of Chemical Technology \& Biotechnology, vol. 88, no. 4, pp. 508-518, 2013.

[112] M. Ghasemi, W. R. W. Daud, S. H. A. Hassan et al., "Nanostructured carbon as electrode material in microbial fuel cells: a comprehensive review," Journal of Alloys and Compounds, vol. 580, pp. 245-255, 2013.

[113] M. Ghasemi, W. R. W. Daud, M. Rahimnejad et al., "Copperphthalocyanine and nickel nanoparticles as novel cathode catalysts in microbial fuel cells," International Journal of Hydrogen Energy, vol. 38, no. 22, pp. 9533-9540, 2013.

[114] D. Park and J. Zeikus, "Impact of electrode composition on electricity generation in a single-compartment fuel cell using Shewanella putrefaciens," Applied Microbiology and Biotechnology, vol. 59, no. 1, pp. 58-61, 2002.

[115] Q. Deng, X. Li, J. Zuo, A. Ling, and B. E. Logan, "Power generation using an activated carbon fiber felt cathode in an upflow microbial fuel cell," Journal of Power Sources, vol. 195, no. 4, pp. 1130-1135, 2010.

[116] A. Ter Heijne, H. V. M. Hamelers, V. De Wilde, R. A. Rozendal, and C. J. N. Buisman, "A bipolar membrane combined with ferric iron reduction as an efficient cathode system in microbial fuel cells," Environmental Science \& Technology, vol. 40, no. 17, pp. 5200-5205, 2006.

[117] J. J. Fornero, M. Rosenbaum, M. A. Cotta, and L. T. Angenent, "Microbial fuel cell performance with a pressurized cathode chamber," Environmental Science \& Technology, vol. 42, no. 22, pp. 8578-8584, 2008.

[118] S. You, Q. Zhao, J. Zhang, H. Liu, J. Jiang, and S. Zhao, "Increased sustainable electricity generation in up-flow aircathode microbial fuel cells," Biosensors and Bioelectronics, vol. 23, no. 7, pp. 1157-1160, 2008.

[119] J. Sun, Y. Hu, Z. Bi, and Y. Cao, "Improved performance of air-cathode single-chamber microbial fuel cell for wastewater treatment using microfiltration membranes and multiple sludge inoculation," Journal of Power Sources, vol. 187, no. 2, pp. 471-479, 2009.

[120] C. J. Sund, S. McMasters, S. R. Crittenden, L. E. Harrell, and J. J. Sumner, "Effect of electron mediators on current generation and fermentation in a microbial fuel cell," Applied
Microbiology and Biotechnology, vol. 76, no. 3, pp. 561-568, 2007.

[121] S. C. Chuo, S. F. Mohamed, S. H. Mohd Setapar et al., "Insights into the current trends in the utilization of bacteria for microbially induced calcium carbonate precipitation," Materials, vol. 13, no. 21, p. 4993, 2020.

[122] R. A. Rozendal, T. H. J. A. Sleutels, H. V. M. Hamelers, and C. J. N. Buisman, "Effect of the type of ion exchange membrane on performance, ion transport, and $\mathrm{pH}$ in biocatalyzed electrolysis of wastewater," Water Science and Technology, vol. 57, no. 11, pp. 1757-1762, 2008.

[123] Y. Zuo, S. Cheng, and B. E. Logan, "Ion exchange membrane cathodes for scalable microbial fuel cells," Environmental Science \& Technology, vol. 42, no. 18, pp. 6967-6972, 2008.

[124] S.-E. Oh and B. E. Logan, "Proton exchange membrane and electrode surface areas as factors that affect power generation in microbial fuel cells," Applied Microbiology and Biotechnology, vol. 70, no. 2, pp. 162-169, 2006.

[125] Z. Du, H. Li, and T. Gu, "A state of the art review on microbial fuel cells: a promising technology for wastewater treatment and bioenergy," Biotechnology Advances, vol. 25, no. 5, pp. 464-482, 2007.

[126] A. Larrosa-Guerrero, K. Scott, I. M. Head, F. Mateo, A. Ginesta, and C. Godinez, "Effect of temperature on the performance of microbial fuel cells," Fuel, vol. 89, no. 12, pp. 3985-3994, 2010.

[127] I. Ieropoulos, J. Greenman, and C. Melhuish, "Improved energy output levels from small-scale microbial fuel cells," Bioelectrochemistry, vol. 78, no. 1, pp. 44-50, 2010.

[128] T. F. Hung, S. H. Liao, C. Y. Li, and Y. W. Chen-Yang, "Effect of sulfonated carbon nanofiber-supported Pt on performance of Nafion-based self-humidifying composite membrane for proton exchange membrane fuel cell," Journal of Power Sources, vol. 196, no. 1, pp. 126-132, 2011.

[129] Y. Cao, H. Mu, W. Liu et al., "Electricigens in the anode of microbial fuel cells: pure cultures versus mixed communities," Microbial Cell Factories, vol. 18, pp. 1-4, 2019.

[130] M. Ghasemi, S. Shahgaldi, M. Ismail, Z. Yaakob, and W. R. W. Daud, "New generation of carbon nanocomposite proton exchange membranes in microbial fuel cell systems," Chemical Engineering Journal, vol. 184, pp. 82-89, 2012.

[131] L. Zhuang, Y. Zheng, S. Zhou, Y. Yuan, H. Yuan, and Y. Chen, "Scalable microbial fuel cell (MFC) stack for continuous real wastewater treatment," Bioresource Technology, vol. 106, pp. 82-88, 2012.

[132] S. S. Dihrab, K. Sopian, M. A. Alghoul, and M. Y. Sulaiman, "Review of the membrane and bipolar plates materials for conventional and unitized regenerative fuel cells," Renewable and Sustainable Energy Reviews, vol. 13, no. 6-7, pp. 16631668, 2009.

[133] Y. Mohan, S. Manojmuthukumar, and D. Das, "Electricity generation using microbial fuel cells," International Journal of Hydrogen Energy, vol. 33, no. 1, pp. 423-426, 2008.

[134] G. Najafpour, M. Rahimnejad, N. Mokhtarian, W. R. W. Daud, and A. Ghoreyshi, "Bioconversion of whey to electrical energy in a biofuel cell using Saccharomyces cerevisiae," World Applied Sciences Journal, vol. 8, pp. 1-5, 2010.

[135] T. Li, Y. Cai, X.-L. Yang, Y. Wu, Y.-L. Yang, and H.-L. Song, "Microbial fuel cell-membrane bioreactor integrated system for wastewater treatment and bioelectricity production: overview," Journal of Environmental Engineering, vol. 146, no. 1, Article ID 04019092, 2020. 
[136] Y.-P. Wang, X.-W. Liu, W.-W. Li et al., "A microbial fuel cell-membrane bioreactor integrated system for cost-effective wastewater treatment," Applied Energy, vol. 98, pp. 230-235, 2012.

[137] V. Chaturvedi and P. Verma, "Microbial fuel cell: a green approach for the utilization of waste for the generation of bioelectricity," Bioresources and Bioprocessing, vol. 3, pp. 1-14, 2016.

[138] J. R. Trapero, L. Horcajada, J. J. Linares, and J. Lobato, "Is microbial fuel cell technology ready? An economic answer towards industrial commercialization," Applied Energy, vol. 185, pp. 698-707, 2017.

[139] D.-J. Lee, J.-S. Chang, and J.-Y. Lai, "Microalgae-microbial fuel cell: a mini review," Bioresource Technology, vol. 198, pp. 891-895, 2015.

[140] A. A. Yazdi, L. D’Angelo, N. Omer, G. Windiasti, X. Lu, and J. Xu, "Carbon nanotube modification of microbial fuel cell electrodes," Biosensors and Bioelectronics, vol. 85, pp. 536552, 2016.

[141] Y. Fan, H. Hu, and H. Liu, "Enhanced Coulombic efficiency and power density of air-cathode microbial fuel cells with an improved cell configuration," Journal of Power Sources, vol. 171, no. 2, pp. 348-354, 2007.

[142] H. Liu, S. Cheng, L. Huang, and B. E. Logan, "Scale-up of membrane-free single-chamber microbial fuel cells," Journal of Power Sources, vol. 179, no. 1, pp. 274-279, 2008. 